\title{
PENINGKATAN PENGETAHUAN DAN SIKAP KADER TENTANG STUNTING PADA BALITA USIA 12 - 36 BULAN MELALUI PENERAPAN APLIKASI ANAK BEBAS STUNTING (ABS)
}

\author{
Titi Purwitasari Handayani1), Vita Murniarti Tarawan2), Juntika Nurihsan³ \\ ${ }^{1}$ Program Studi Magister Kebidanan FK Unpad \\ Email: titipurwitasarih30@gmail.com \\ 2 Departemen Obstetri dan Gynekologi FK Unpad \\ Email: vita13lubis@gmail.com \\ ${ }^{3}$ Fakultas Psikologi Ilmu Pendidikan Universitas Pendidikan Indonesia \\ Email: juntikanurihsan@upi.edu
}

\begin{abstract}
Background :Nutritional Problems in Indonesia are still high, incdence of stunting in Indonesia in 2013 was around $37.2 \%$, exceeding the standard set at $20 \%$. The effect of stunting on toddlers results in the inhibition of cognitive development which affects intelligence, dexterity of thinking and work productivity. Knowledge of good cadres and positive attitudes can improve the quality of service and conduct early detection assessments in the beginning of stunting and nutritional problems in the community. The application Anak Bebas Stunting (ABS) containing information about stunting is expected to be able to increase the knowledge and attitudes of cadres so that they are able to carry out initial assessments.

Purpose: The aim of the study was to analyze the effect of application Anak Bebas Stunting (ABS) on increasing the knowledge and attitudes of cadres about stunting in infants aged 12 - 36 months.

Method: The quasi experimental design of one group pre test and post test was conducted in the work area of Leuwigoong Health Center.

Result: The research subjects were 80 cadres with simple random sampling. The results showed that the increase in knowledge and attitudes of cadres after being given a Application Anak Bebas Stuntig (ABS) with a value of $p<0.005$, the percentage increase in knowledge was $25.1 \%$ and the attitude percentage was $76.2 \%$.

Conclusion: Conclusions of the study were the influence of the application Anak Bebas Stunting (ABS) to the increase of cadre knowledge and attitudes about stunting.

Sugestion: ABS application can be utilized and used to assist the management of posyandu by cadres
\end{abstract}

Keywords: Application ABS, cadres, Knowledge, Attitude

\section{ABSTRAK}

Latar Belakang : Permasalahan Gizi di Indonesia masih tinggi, dengan angka kejadian stunting di Indonesia tahun 2013 sekitar 37,2\%, melebihi dari standar yang ditetapkan yaitu 20\%. Efek stunting pada balita mengakibatkan terhambatnya perkembangan kognitif yang berpengaruh terhadap kecerdasan, ketangkasan berpikir serta produktivits kerja. Pengetahuan kader yang baik dan sikap positif mampu meningkatkan kualitas pelayanan dan melakukan penilaian deteksi dini secara awal terjadinya stunting maupun masalah gizi di masyarakat. Aplikasi Anak Bebas Stunting (ABS) berisikan informasi mengenai stunting diharapkan mampu meningkatkan pengetahuan dan sikap kader sehingga mampu melakukan penilaian awal.

Tujuan : untuk menganalisis pengaruh aplikasi anak bebas stunting (ABS) terhadap peningkatan pengetahuan dan sikap kader tentang stunting pada balita usia $12-36$ bulan.

Metode : Desain penelitian quasi experiment one group pre test and post test, dilakukan di wilayah kerja Puskesmas Leuwigoong,. Subjek penelitian 80 orang kader dengan simple random sampling.

Hasil penelitian : didapatkan bahwa terhadap peningkatan pengetahuan dan sikap kader setelah diberikan Aplikasi Anak Bebas Stunting (ABS) dengan nilai $p<0,005$, presentase peningkatan pengetahuan $25,1 \%$ dan persentase sikap $76,2 \%$.

Simpulan : penelitian terdapat pengaruh penerapan aplikasi Anak Bebas Stunting (ABS) terhadap peningkatan pengetahuan dan sikap kader tentang stunting .

Saran : Aplikasi ABS dapat di manfaatkan dan digunakan untuk membantu penatalaksanaan posyandu yang dilakukan kader

Kata kunci : Aplikasi ABS, kader, Pengetahuan, Sikap 


\section{PENDAHULUAN}

Permasalahan gizi berdampak terhadap kualitas sumber daya manusia (SDM). Berdasarkan data dari Global Nutrition Report tahun 2013 dari WHO menunjukkan Indonesia termasuk dalam 17 negara diantara 117 negara yang mempunyai tiga masalah gizi yaitu stunting $(37,2 \%)$, wasting $(12,1 \%)$, dan overweight $(11,9 \%)$ pada balita. Oleh karena itu masalah gizi masih cukup tinggi di Indonesia terutama masalah pendek (stunting) dan kurus (wasting) pada balita. (Achadi,2014)

Hasil Riset Kesehatan Dasar (Riskesdas) mengenai prevalensi balita pendek dan sangat pendek di Indonesia Tahun 2013 adalah 37,2\%, dibandingkan tahun 2010 (35,6\%) dan tahun 2007 $(36,8 \%)$, menunjukkan penurunan/ perbaikan yang tidak signifikan. Disebabkan oleh standar WHO, bahwa prevalensi balita pendek menjadi masalah kesehatan jika prevalensinya $20 \%$ atau lebih. (Riskesdas, 2013)

Provinsi Jawa Barat pada tahun 2017 memiliki prevalensi stunting sebanyak $29,2 \%$. Di Kabupaten Garut status gizi balita pendek menempati urutan pertama dari 27 Kabupaten di Jawa Barat tahun 2017 sekitar 43,2 \%. (Dinkes Garut, 2017)

Stunting didefinisikan sebagai keadaan tubuh yang pendek atau sangat pendek didasarkan pada indeks Panjang Badan menurut Umur (PB/U) atau Tinggi Badan menurut Umur (TB/U) dengan ambang batas (z-score) antara -3 SD sampai dengan < -2 SD. Stunting pada anak merupakan hasil jangka panjang konsumsi kronis diet berkualitas rendah yang dikombinasikan dengan morbiditas, penyakit infeksi dan masalah lingkungan. (WHO,2010)

Kader merupakan anggota masyarakat yang memiliki waktu untuk membantu mengidentifikasi kebutuhan akan kesehatan di masyarakat. Pengetahuan yang baik serta sikap positif akan menghasilkan pelayanan pelayanan yang baik. Sikap kader dalam pelayanan posyandu menunjukkan sikap positif akan bertanggung jawab dalam melaksanakan tugasnya untuk meningkatkan derajat kesehatan masyarakat. (Kemenkes,2017)

Penelitian mengenai pengetahuan kader kesehatan tentang deteksi dini gizi buruk pada balita didapatkan hanya 39\% kader yang memiliki pengetahuan yang baik tentang deteksi gizi buruk. Oleh karena itu diperlukan suatu program kegiatan untuk kader dalam meningkatkan kemampuan deteksi dini status gizi pada balita. Hal ini dilakukan untuk meningkatkan kemandirian dan kemampuan kader dalam mewujudkan pembangunan kesehatan masyarakat. (Fuada, Salimar, Irawati, 2017)
Ponsel dapat menawarkan peluang baru untuk mengatasi serta mendukung pemberian layanan gizi termasuk pemantauan pertumbuhan anak dan konseling nutrisi. Aplikasi telepon seluler berpotensi memberi keyakinan kepada kader dalam penilaian dan waktu yang dibutuhkan lebih singkat untuk penilaian awal.

Penggunaan teknologi seluler pada penelitian yag dilakukan Otu $A$, Ebenso $B$, Okuzu $O$ dan Dawodu EO menunjukkan inovasi mHealth dapat membantu meringankan beberapa kendala sistem kesehatan seperti kurangnya alat untuk mengumpulkan data, dan terbatasnya akses ke pelatihan dibidang kesehatan seperti kesehatan ibu dan anak, dan kesehatan reproduksi. mHealth meningkatkan fungsi sistem kesehatan dan pengetahuan sebanyak $11 \%$ dari sebelumnya serta perubahan sikap terhadap penyakit. (Otu, Ebenso, Okuzu dan Dawudo,2016)

Berdasarkan studi pendahuluan wilayah kabupaten Garut terdapat 7 kecamatan yang memiliki balita stunting salah satunya yaitu kecamatan Leuwigoong merupakan kecamatan yang memiliki angka stunting yang tinggi di antara 7 kecamatan yaitu $15,48 \%$ dengan jumah anak balita pendek 24 dan sangat pendek 100. (Dinkes Garut, 2017)

Aplikasi "ABS (Aplikasi Bebas Stunting)" merupakan software untuk melakukan deteksi dini kejadian stunting pada anak oleh kader. Pengembangan aplikasi ini diharapkan mampu membantu kader untuk mendeteksi secara dini kejadian stunting terutama ketika pelaksanaan posyandu, sehingga ketika ditemukaannya kejadian stunting kader akan melaporkannya pada petugas kesehatan. Selain melakukan deteksi dini, aplikasi ini memberikan informasi mengenai informasi stunting dalam bentuk gambar yang menarik, video bagaimana melakukan pengukuran tinggi badan dengan tepat pada balita dan membantu kader untuk deteksi dini status gizi balita.

Berdasarkan latar belakang tersebut, penulis melakukan penelitian "Pengaruh Penerapan Aplikasi Anak Bebas Stunting (ABS) terhadap Peningkatan Pengetahuan dan Sikap Kader tentang Stunting pada Balita Usia 12 - 36 bulan di Wilayah Kerja Puskesmas Leuwigoong Kabupaten Garut"

\section{METODE PENELITIAN}

Metode penelitian menggunakan metode kuantitatif, untuk menganalisis pengaruh penerapan aplikasi Anak Bebas Stunting (ABS) terhadap peningkatan pengetahuan dan sikap kader tentang stunting di wilayah kerja Puskesmas 
Leuwigoong Kabupaten Garut. Variabel Bebas adalah penerapan aplikasi Anak Bebas Stunting, variabel terikat adalah Pengetahuan dan Sikap Kader.

Populasi target dalam penelitian ini adalah seluruh kader posyandu di wilayah kerja Puskesmas Leuwigoong. Populasi terjangkau dalam penelitian ini adalah seluruh kader posyandu di wilayah Desa Leuwigoong Kecamatan Leuwigoong Kabupaten Garut.

Sampel pada penelitian ini adalah sebagian Kader Posyandu di wilayah desa Leuwigoong pada periode penelitian yang memenuhi kriteria inklusi dan tidak termasuk kriteria eksklusi serta bersedia mengikuti penelitian dengan menandatangani lembar persetujuan responden. Teknik pengambilan sampel menggunakan simple random sampling. Wilayah kerja Puskesmas Leuwigoong memiliki empat desa yaitu Desa Leuwigoong, Desa Margacinta, Desa Margahayu, dan Sindang Rasa. Puskesmas Leuwigoong memiliki 45 Posyandu dengan Jumlah Kader 220 orang. Berdasarkan rumus ukuran sampel diperlukan minimal sampel 74 , mempermudah perhitungan diambil 80 sampel.

Jenis penelitian quasi eksperimental dengan rancangan one group pre test post test design. subjek penelitian ini hanya terjadi pada satu kelompok saja, dilakukan pre test kemudian dilanjutkan dengan perlakuan aplikasi dan post test setelah diberikan aplikasi untuk menganalisis pengaruh penerapan aplikasi Anak Bebas Stunting (ABS) terhadap peningkatan pengetahuan kader tentang stunting. Data primer yaitu hasil penilaian kuesioner pengetahuan dan sikap kader tentang stunting.

Instrumen yang digunakan dalam penelitian berupa kuesioner pengetahuan dan sikap tentang sikap. Pada tahap pertama dilakukan pengukuran awal (pre test) pada kelompok. Kemudian kelompok diberikan perlakuan, dilakukan pengukuran akhir (post test).

Penelitian ini sudah mendapat pembebasan etik dengan Nomor 1477/ UN6. KEP/ EC/2018 dari Komisi Etik Penelitian Universitas Padjadjaran Bandung.

\section{HASIL DAN PEMBAHASAN}

Tabel 1 Karakteristik Subjek Riset $(n=80)$

\begin{tabular}{|c|c|c|c|}
\hline \multirow{2}{*}{\multicolumn{4}{|c|}{$\begin{array}{ll} & \text { Karakteristik } \\
\text { 1. Usia }\end{array}$}} \\
\hline & & & \\
\hline & $20-25$ tahun & 8 & 10 \\
\hline & $26-35$ tahun & 17 & 21 \\
\hline & $36-45$ tahun & 30 & 38 \\
\hline & $46-50$ tahun & 25 & 31 \\
\hline \multirow[t]{4}{*}{2.} & Pendidikan & & \\
\hline & SD & 11 & 14 \\
\hline & SMP & 42 & 53 \\
\hline & $\geq S M A$ & 27 & 34 \\
\hline \multirow[t]{3}{*}{3.} & Pekerjaan & & \\
\hline & Tidak Bekerja & 76 & 95 \\
\hline & Bekerja & 4 & 5 \\
\hline \multirow[t]{4}{*}{4.} & Pengalaman menjadi kader & & \\
\hline & $<5$ tahun & 20 & 25 \\
\hline & $5-10$ tahun & 43 & 54 \\
\hline & $>10$ tahun & 17 & 21 \\
\hline
\end{tabular}

Berdasarkan tabel 1 diketahui karakteristik dari 80 orang kader yang terlibat dalam penelitian ini usia paling banyak sebesar $38 \%$ responden rentang usia 36 - 45 tahun. Karakteristik dari responden yang berjumlah 80 orang kader paling bnyak sebesar $53 \%$ responden berpendidikan SMP, sementara $14 \%$ berpendidikan SD. Karakteristik responden berdasarkan pekerjaan 95\% tidak bekerja, sementara 5\% kader yang bekerja. Karakteristik responden berdasarkan pengalaman menjadi kader $54 \%$ responden pengalaman $5-10$ tahun, sementara $21 \%$ responden pengalaman menjadi selama $>10$ tahun.

Tabel 2 Deskriptif statistik Skor Pengetahuan dan Sikap sebelum dan sesudah diberikan aplikasi ABS (Anak Bebas Stunting)

\begin{tabular}{|c|c|c|c|c|c|}
\hline \multirow{2}{*}{\multicolumn{2}{|c|}{$\begin{array}{l}\text { Variabel } \\
\text { (Skor 100) }\end{array}$}} & \multicolumn{3}{|c|}{ Ukuran Statistik } & \multirow{2}{*}{$\begin{array}{l}\text { Uji Normalitas Data } \\
\text { (Nilai p })^{*}\end{array}$} \\
\hline & & $\bar{x}(\mathrm{SD})$ & Median & Rentang & \\
\hline 1 & $\begin{array}{c}\text { Skor Pengetahuan } \\
\text { - } \quad \text { Pre Test } \\
\text { - }\end{array}$ & $\begin{array}{c}65,4(10,2) \\
82,6(9,9)\end{array}$ & $\begin{array}{l}66,7 \\
80,0\end{array}$ & $\begin{array}{c}33,3-93,3 \\
60,0-100,0\end{array}$ & $\begin{array}{l}<0,001 \\
<0,001\end{array}$ \\
\hline 2 & $\begin{aligned} \text { Skor Sikap } & \\
- & \text { Pre Test } \\
- & \text { Post Test }\end{aligned}$ & $\begin{array}{l}69,6(9,0) \\
74,5(8,3)\end{array}$ & $\begin{array}{l}69,2 \\
74,3\end{array}$ & $\begin{array}{l}53,8-89,7 \\
56,4-92,3\end{array}$ & $\begin{array}{l}0,200 \\
0,200\end{array}$ \\
\hline
\end{tabular}

Keterangan : *) Uji Kolmogorov - Smirnov, Data berdistribusi normal jika $p>0,05$ 
Berdasarkan tabel 2 hasil pengujian normalitas data pengetahuan sebelum dan sesudah pemberian aplikasi menghasilkan nilai $p<0,001$ sehingga data pengetahuan sebelum dan sesudah pemberian aplikasi dinyatakan tidak berdistribusi normal. Hasil pengujian normalitas data sikap sebelum dan sesudah pemberian aplikasi menghasilkan nilai $p \quad 0,200$ sehingga data sikap sebelum dan sesudah pemberian aplikasi dinyatakan berdistribusi normal.

Tabel 3 Perbandingan Skor Pengetahuan Sebelum dan Sesudah diberikan aplikasi ABS (Anak Bebas Stunting)

\begin{tabular}{|c|c|c|c|}
\hline Variabel skala (100) & & Pengetahuan & \\
\hline Skor Pengetahuan & Pre Test & Post Test & Nilai $p^{*}$ \\
\hline $\begin{array}{l}\text { Median } \\
\text { Rentang }\end{array}$ & $\begin{array}{l}66,7 \\
33,3-93,3\end{array}$ & $\begin{array}{l}80,0 \\
60,0-100,0\end{array}$ & $<0,001$ \\
\hline Peningkatan Pengetahuan & & $25,1 \%$ & \\
\hline
\end{tabular}

Berdasarkan tabel 3 hasil pengujian diketahui nilai $p<0,001$ menggunakan uji wilcoxon, sehingga diketahui bahwa nilai $p<0,05$, dengan demikian dapat dinyatakan bahwa terdapat perbedaan yang signifikan antara pengetahuan sebelum dan sesudah pemberian aplikasi anak bebas stunting kepada kader. Median \% peningkatan pengetahuan kader tentang stunting sebelum dan sesudah diberikan aplikasi ABS (Anak Bebas Stunting) adalah sebesar $25,1 \%$.

Tabel 4 Perbandingan Skor Sikap Sebelum dan Sesudah diberikan aplikasi ABS (Anak Bebas Stunting)

\begin{tabular}{llll}
\hline Variable skala (100) & \multicolumn{2}{c}{ Sikap } & \multirow{2}{*}{ Nilai $p^{*}$} \\
\cline { 2 - 3 } Skor Sikap & Pre Test & Post Test & \multirow{2}{*}{$<0,001$} \\
\hline $\bar{x}(\mathrm{SD})$ & $69,6(9,0)$ & $74,5(8,3)$ & \\
Rentang & $53,8-89,7$ & $56,4-92,3$ & \\
\hline \%Peningkatan Sikap & & $76,2 \%$ & \\
\hline
\end{tabular}

Keterangan*) Uji T Test Berpasangan

Tabel 5 Perbedaan Peningkatan Pengetahuan dan Sikap Berdasarkan Karakteristik Responden

\begin{tabular}{|c|c|c|c|c|c|c|}
\hline \multirow[t]{2}{*}{ Karakteristik } & \multicolumn{2}{|c|}{$\begin{array}{l}\text { \% Peningkatan } \\
\text { Pengetahuan }\end{array}$} & \multirow[t]{2}{*}{ Nilai $p$} & \multicolumn{2}{|c|}{ \%Peningkatan Sikap } & \multirow[t]{2}{*}{ Nilai $p$} \\
\hline & Median & Rentang & & $\bar{x}(\mathrm{SD})$ & Rentang & \\
\hline 1. Usia & & & $0,569^{*}$ & & & $0,030^{\star *}$ \\
\hline $20-25$ & 25,1 & $9,9-36,4$ & & $132,6(103,3)$ & $0,0-17,9$ & \\
\hline $26-35$ & 22,1 & $7,1-42,8$ & & $105,9(86,4)$ & $0,0-304,3$ & \\
\hline $36-45$ & 27,2 & $7,6-56,9$ & & $53,6(48,9)$ & $0,0-208,3$ & \\
\hline $\begin{array}{l}46-50 \\
\text { 2. Pendidikan }\end{array}$ & 25,1 & $8,3-100$ & & $64,8(75)$ & $0,0-291,6$ & \\
\hline SD & 33,3 & $9,1-100$ & $0,119^{*}$ & 39,7 & $0,0-173,9$ & $0,020^{\star *}$ \\
\hline SMP & 22,1 & $7,6-56,9$ & & 93,9 & $0,0-333,3$ & \\
\hline $\begin{array}{l}>=\text { SMA } \\
\text { 3. Pekerjaan }\end{array}$ & 27,2 & $7,1-55,5$ & & 63,3 & $0,0-291,6$ & \\
\hline Tidak Bekerja & 25,1 & $7,1-100$ & $0,924^{\star * *}$ & 75,5 & 87,1 & $0,448^{* * *}$ \\
\hline Bekerja & 27,7 & $18,2-36,4$ & & $0,0-3333,3$ & $\begin{array}{l}62,5 \\
148,1\end{array}$ & \\
\hline \multicolumn{7}{|c|}{ 4. Pengalaman Menjadi Kader } \\
\hline$<5$ tahun & 31,6 & $9,9-42,8$ & $0,100^{*}$ & 78,8 & $0,0-333,3$ & $0,421^{* *}$ \\
\hline 5-10 tahun & 25,1 & $7,6-100$ & & 67,3 & $0,0-291,6$ & \\
\hline$>10$ tahun & 19,9 & $7,1-44,5$ & & 95,3 & $0,0-272,7$ & \\
\hline
\end{tabular}

Keterangan $\left.{ }^{*}\right)$ Uji Kruskal Walis, ${ }^{* *}$ ) Uji An Nova, ${ }^{* * *}$ ) Uji Mann Whitney, ${ }^{* * *}$ ) Uji T Test 
Berdasarkan hasil pengujian pada tabel 4 dapat diketahui bahwa nilai $p<0,001$. Hal ini berarti nilai $p<0,05$, dengan demikian dapat dinyatakan bahwa perbedaan yang signifikan sikap sebelum dan sesudah pemberian informasi melalui aplikasi anak bebas stunting. Rerata \% peningkatan sikap sebelum dan sesudah pemberian informasi melalui aplikasi anak bebas stunting 76,2\%.

Berdasarkan hasil pengujian pada tabel 5 dapat diketahui bahwa perbedaaan pengetahuan kader berdasarkan usia, pendidikan, pekerjaan dan pengalaman menjadi kader dengan pemberian informasi melalui aplikasi anak bebas stunting didapatkan hasil $p>0,05$, dapat dinyatakan bahwa tidak terdapat perbedaan yang signifikan peningkatan pengetahuan kader. Hal ini menunjukkan bahwa usia, pendidikan, pekerjaan, dan pengalaman tidak dapat digunakan sebagai faktor perancu (confounding) karena tidak memiliki pengaruh terhadap peningkatan pengetahuan kader.

Bahwa perbedaaan sikap kader berdasarkan pekerjaan dan pengalaman menjadi kader dengan pemberian informasi melalui aplikasi anak bebas stunting didapatkan hasil $p>0,05$, dapat dinyatakan bahwa tidak terdapat perbedaan yang signifikan peningkatan sikap kader. Berdasarkan usia dan pendidikan didapatkan hasil $p<0,05$, hal ini menunjukkan bahwa usia, pendidikan menjadi kader merupakan faktor perancu (confounding) karena memiliki pengaruh terhadap peningkatan sikap kader.

\section{PEMBAHASAN}

Berdasarkan hasil uji statistik pada tabel 2 diperoleh bahwa skor pengetahuan pretest dan postetst tidak berdistribusi normal, selanjutya dilakukan analisis pada tabel 3 bahwa nilai $p<0,001$, sehingga dinyatakan terdapat perbedaan yang signifikan antara pengetahuan sebelum dan sesudah diberikan aplikasi. Hasil penelitian menunjukan bahwa nilai median skor antara pre test dan post test. Terdapat median \% peningkatan pengetahuan kader sebesar $25,1 \%$.

Penggunaan teknologi seluler pada penelitian yag dilakukan Otu A, Ebenso B, Okuzu O dan Dawodu EO menunjukkan inovasi mHealth dapat membantu meringankan beberapa kendala sistem kesehatan seperti kurangnya alat untuk mengumpulkan data, dan terbatasnya akses ke pelatihan dibidang kesehatan seperti kesehatan ibu dan anak, dan kesehatan reproduksi. mHealth meningkatkan fungsi sistem kesehatan dan pengetahuan sebanyak $11 \%$ dari sebelumnya serta perubahan sikap terhadap penyakit. (Otu, Ebenso, Okuzudan Dawodu, 2016)

Pengetahuan yang baik mengenai pertumbuhan pada balita dapat dipengaruhi oleh media yang digunakan pada saat pemberian informasi. Tujuan dari aplikasi Anak Bebas Stunting adalah untuk meningkatkan pengetahuan dan sikap kader agar kader mampu mendeteksi dini jika menemukan adanya permasalahan pertumbuhan yang terjadi pada balita pada saat posyandu.

Media pendidikan berfungsi untuk mengerahkan indera sebanyak mungkin kepada suatu objek sehingga mempermudah persepsi. Media pendidikan membuat seseorang dapat lebih mengerti informasi atau materi yang dianggap rumit menjadi lebih mudah. Penggunaan media akan membantu memperjelas informasi yang disampaikan, karena dapat lebih menarik, lebih interaktif, dapat mengatasi batasan ruang, waktu dan indra manusia. Agar informasi yang disampaikan bisa lebih jelas dan mudah dipahami sesuai dengan tujuan yang akan dicapai, maka informasi tersebut perlu dikemas sesuai dengan karakteristik dari setiap media yang digunakan.

Ponsel saat ini tidak hanya berfungsi sebagai sarana telekomunikasi, namun telah beralih menjadi gadget yang mampu melakukan banyak hal. Ponsel jenis ini sekarang lebih dikenal dengan isitilah smartphone. Smartphone dapat digunakan untuk membantu kegiatan medis, seperti halnya penetapan diagnosis dan terapi. Dari berbagai bentuk teknologi informasi dan telekomunikasi, ponsel dianggap menjadi alat yang sangat cocok untuk memajukan pendidikan didaerah berkembang. Penggunaan smartphone ini lebih efektif dibandingkan modul tanpa aplikasi. (Barnett, Befani, Sulistyo , 2014). Penelitian Wahyuni T mengenai pengaruh aplikasi smartphone terhadap pengetahuan dan keterampilan seseorang dalam melakukan stimulasi tumbuh kembang balita, menunjukkan terjadinya peningkatan pengetahuan maupun keterampilan. Oleh sebab itu, pemberian informasi melalui sarana media yang menarik akan memudahkan seseorang melakukan stimulasi secara mandiri. (Wahyuni, 2017)

Berdasarkan hasil uji statistik pada tabel 2 diperoleh bahwa skor sikap pretest dan postetst berdistribusi normal, selanjutya dilakukan analisis pada tabel 3 bahwa nilai $p<0,001$, sehingga dinyatakan terdapat perbedaan yang signifikan antara pengetahuan sebelum dan sesudah diberikan aplikasi. Hasil penelitian menunjukan bahwa nilai median skor antara pre test dan post test. Terdapat median \% peningkatan pengetahuan kader sebesar $76,2 \%$. 
Sikap kader merupakan cerminan dari persepsi kader terhadap tugas-tugas yang diembannya termasuk deteksi dini perkembangan. Semakin baik sikap kader maka kader memiliki persepsi yang positif terhadap tugasnya dalam deteksi dini perkembangan sehingga kader dapat melaksanakannya dengan baik. (Pakasi, Korah, Imbar,2016)

Penelitian mengenai Pelatihan deteksi dini dan stimulasi tumbuh kembang anak pada Kader Posyandu dapat memberikan pengaruh berupa meningkatnya pengetahuan dan sikap di antara kader dalam melakukan deteksi dini tumbuh kembang anak. Hasil yang berbeda di tunjukan setelah diberikan pelatihan (post-test) yakni kader peningkatan menjadi sebanyak $92,2 \%$ dan peningkatan sebanyak $73,7 \%$. (Fuada, Salimar, Irawati, 2014)

Hasil penelitian Ai Mardhiyah, Aat Sriati dan Ayu Prawesti, melalui pelatihan akan meningkatkan sikap kader terutama dalam melakukan dteksi dini tumbuh kembang pada balita sehingga apabila ada anak yang terdeteksi mengalami gangguan tumbuh kembang dapat segera dilakukan intervensi dan dirujuk. (Mardiyah, Sriati, Prawesti, 2017).

Hasil penelitian mengenai pemberian modul terintegrasi posyandu meningkatkan sikap kader untuk melaksanakan fungsi posyandu.Sikap dikatakan sebagai suatu proses evaluatif yang timbul apabila individu dihadapkan pada suatu stimulus yang menghendaki adanya reaksi individual. Sikap timbul berdasarkan proses evaluasi dalam diri individu yang memberi kesimpulan terhadap stimulus dalam bentuk nilai baik buruk, positif negatif, menyenangkan tidak menyenangkan. Struktur sikap terdiri dari tiga komponen yang saling menunjang yaitu komponen kognitif, afektif, dan konatif. Komponen kognitif merupakan representasi yang dipercayai oleh individu pemiliki sikap, komponen afektif merupakan perasaan yang menyangkut aspek emosional, dan konatif merupakan aspek kecenderungan berperilaku tertentu sesuia dengan sikap yang dimlliki seseorang. (Adisti, Maryam,Lumbantobing, 2017)

Penelitian mengenai kemampuan kader posyandu dalam melakukan pengukuran panjang / tinggi badan balita menunjukkan hanya 30 persen kegiatan posyandu yang dilaksanakan dengan benar. Pelatihan pengukuran panjang / tinggi badan sesuai dengan alat yang terstandarisasi (gold standard) memiliki kontribusi terhadap peningkatan sekitar $30-40$ persen dari kemampuan awal sebelum pelatihan. Hal ini menjelaskan bahwa, pentingnya pelatihan kepada kader untuk meningkatkan kemampuan kader dalam melakukan pengukuran sehingga mengurangi kesalahan dalam menentukan status gizi balita. (Nura, Hardiningsih, Astrika,2017)

Penelitian ini didapatkan bahwa aplikasi ABS (Anak Bebas Stunting) sebagai media pendidikan tentang pertumbuhan pada balita terutama stunting berpengaruh untuk meningkatkan pengetahuan dan sikap kader mengenai stunting. Aplikasi ini digunakan untuk memudahkan kader untuk mendapatkan informasi mengenai pertumbuhan pada anak balita sehingga mampu mendeteksi dini permasalahan gizi terutama pada pertumbuhan balita yang ada dilingkungan masyarakat

\section{SIMPULAN}

Terdapat pengaruh penerapan aplikasi Anak Bebas Stunting (ABS) terhadap peningkatan pengetahuan kader tentang stunting pada balita usia 12 - 36 bulan di wilayah kerja Puskesmas Leuwigoong Kabupaten Garut.Terdapat pengaruh penerapan aplikasi Anak Bebas Stunting (ABS) terhadap peningkatan pengetahuan kader tentang stunting pada balita usia 12 - 36 bulan di wilayah kerja Puskesmas Leuwigoong Kabupaten Garut.

\section{SARAN}

Aplikasi ABS dapat di manfaatkan dan digunakan untuk membantu penatalaksanaan posyandu yang dilakukan kader, Aplikasi Anak Bebas Stunting membantu kader melakukan penyuluhan tentang stunting yang terjadi pada pertumbuhan balita sehingga masyarakat bisa terpapar informasi,diperlukan penelitian lebih lanjut untuk mengukur kemampuan kader dalam menilai status gizi dan intensitas waktu kader dalam mengakses aplikasi,penelitian pengetahuan dan sikap sebaiknya dilakukan dalam jangka waktu yang lama,memperbaiki isi konten aplikasi dengan adanya pemberitahuan mengenai informasi

\section{DAFTAR PUSTAKA}

Achadi EL. Masalah Gizi di Indonesia dan Posisinya secara Global. MCA. 2014.

Adistie F, Maryam NNA, Lumbantobing VB. Pengetahuan Kader Kesehatan tentang Deteksi Dini Gizi Buruk pada Balita. Jurnal Aplikasi Ipteks Untuk Masyarakat. 2017;6(3).

Barnett I, Befani B, Sulistyo S, editors. Designing an impact evaluation for a mobile phone application for nutrition service delivery in Indonesia. CDI Development Seminar; 2014.

Balitbankes. Riset Kesehatan Dasar. 2013. Jakarta 
DINKES GARUT. BPB (Bulan Penimbangan Balita) tahun 2017. 2017.

Fuada N, Salimar, Irawati A. Kemampuan Kader Posyandu Dalam Melakukan Pengukuran Panjang / Tinggi Badan Balita. Jurnal Ekologi Kesehatan. 2014;13(3):229-39.

Kemenkes RI. Data dan Informasi Profil Kesehatan Indonesia 2017. Jakarta: Kemenkes Rl; 2018.

Kementrian Desa Pembangunan Daerah Terpencil dan Transmigrasi. Buku Saku Desa Dalam Penanganan Stunting. Jakarta.2017.

KEPUTUSAN MENTERI KESEHATAN RI NO.1995/MENKES/SK/XII/2010 tentang Standar Antropometri Penilaian Status Gizi Anak. 2010.

Nurma AE, Hardiningsih, Astrika F. Pengaruh Penyuluhan Tentang Posyandu Terhadap Pengetahuan Kader di Wilayah Puskesmas Colomadu I dan II Kabupaten Karanganyar. 2017.

Mardhiyah A, Sriati A, Prawesti A. Analisis Pengetahuan dan Sikap Kader Tentang Deteksi Dini Tumbuh Kembang Anak di Desa Pananjung, Kabupaten Pangandaran. Jurnal Pengabdian Kepada Masyarakat. $2017 ; 1$.
Utomo BS. Gizi Menjadi Penentu Masa Depan Bangsa.2017.

Pakasi AM, Korah BH, Imbar HS. Hubungan Pengetahuan Dan Sikap Kader Kesehatan Dengan Pelayanan Posyandu. Jurnal IImiah Bidan. 2016;1.

Otu A, Ebenso B, Okuzu O, Dawodu EO. Using a mHealth tutorial application to change knowledge and attitude of frontline health workers to Ebola virus disease in Nigeria: a before and after study. Human Resources for health. 2016;14(5).

Wahyuni T. Pengaruh Aplikasi Mother Cares Terhadap Peningkatan Pengetahuan dan Keterampilan Orang Tua Dalam Melakukan Stimulasi Tumbuh Kembang Balita Usia 12 18 Bulan. Medika Cendikia. 2017;4(1).

WHO. Nutrition Landscape Information System (NLIS) country profile indicators: interpretation guide. Switzerland: WHO; 2010.

WHO. WHO Child Growth Standards 1 year 2 years 3 years 4 years 5 years Head circumferencefor-age, arm circumference-for-age, triceps skinfold-for-age and subscapular skinfold-forage. 2007. 